\title{
Kepatuhan menelan obat, merokok dan resiko kegagalan konversi (BTA positif) pada pasien tuberculosis
}

\author{
Mariawati $^{1 *}$, Khoidar Amirus², Marliyana ${ }^{3}$ \\ 1Puskesmas Poncowati Lampung Tengah. *Email: mariawati0678@gmail.com \\ ${ }^{2}$ Fakultas Kesehatan Masyarakat, Universitas Malahayati \\ ${ }^{3}$ Akademi Keperawatan Baitul Hikmah Bandar Lampung
}

\section{Abstract \\ Active smokers, treatment compliance and sputum smear conversion failed among patients treated for active tuberculosis}

Background: One of the infectious diseases that often affects people is pulmonary tuberculosis (pulmonary TB). World data, there are 10.4 million recent cases of tuberculosis or 142 cases / 100,000 populations, with 480,000 cases of failed conversions. Indonesia is a country with the second largest number of recent cases in the world after India. With the success of treatment in Indonesia, it is low at $85 \%$. Data from Lampang Province, the number of new patients with pulmonary tuberculosis is reaching 110 per 100,000 populations. Data in Central Lampung Regency found 954 cases out of 20,184 people suspected (4.73\%). Data in Poncowati Public Health Center in Central Lampung in 2018, conversion failure rates were quite high at 16 people out of 42 people with pulmonary TB $(38.1 \%)$, and the success of the treatment is also still low, at $76.2 \%$ (target> $90 \%$ ).

Purpose: Knowing relation factors active smoker, treatment compliance with failed sputum smear conversion among patients treated for active tuberculosis.

Method: A quantitative study with the design by observational analytic. The samples in this study were 42 pulmonary TB patients. Data analysis in this study used the chi-square test.

Results: Most respondents smoke $<10$ cigarettes per day (not at risk), $22(52.4 \%)$. Most respondents obey the ingestion of drugs, which are $28(66.7 \%)$. There was a correlation between active smoking ( $p$-value $=0.002$ and $\mathrm{OR}=$ 11.762 ) and medication adherence ( $p$-value $=0.002$ and $O R=9,167$ ) with conversion failure in pulmonary tuberculosis patients.

Conclusion: There were active smokers, treatment compliance, and sputum smear conversion failed among patients treated for active tuberculosis. It needs to further improve Directly Observed Therapy (DOT) support and the role of health workers in improving patient treatment compliance and motivation in quitting smoking.

\section{Keywords : Active smoking; Medication adherence; Conversion failure; Active tuberculosis}

Pendahuluan: Salah satu penyakit menular yang sering diderita masyarakat adalah Tuberculosis paru (TB paru). Data dunia, terdapat 10,4 juta kasus baru tuberkulosis atau 142 kasus/100.000 populasi, dengan 480.000 kasus gagal konversi. Indonesia merupakan negara dengan jumlah kasus baru terbanyak kedua di dunia setelah India. Dengan angka keberhasilan pengobatan di Indonesia rendah, yaitu 85\%. Data Provinsi Lampung, jumlah pasien baru tuberculosis paru yaitu mencapai 110 per 100.000 penduduk. Data di Kabupaten Lampung Tengah ditemukan sebanyak 954 kasus dari 20.184 orang suspek (4,73\%).Data di Puskesmas Poncowati Lampung Tengah pada tahun 2018, angka kegagalan konversi cukup tinggi yaitu sebanyak 16 orang dari 42 orang penderita TB paru $(38,1 \%)$, dan keberhasilan pengobatan juga masih rendah, yaitu $76,2 \%$ (target $>90 \%$ ).

Tujuan: Diketahui hubungan para perokok aktif, kepatuhan menelan obat dan kegagalan konversi (BTA positif) pada pasien tuberculosis.

Metode: Jenis penelitian kuantitatif, rancangan penelitian dengan analitik observasional. Sampel sejumlah 42 pasien TB paru. Analisis data pada penelitian ini menggunakan uji chi-square.

Hasil: Sebagian besar responden merokok $<10$ batang perhari (tidak berisiko) yaitu sebanyak 22 orang $(52,4 \%)$.Sebagian besar responden patuh dalam menelan obat, yaitu sebanyak 28 orang $(66,7 \%)$. Terdapat hubungan antara merokok aktif ( $p$-value $=0,002$ dan $O R=11,762)$ dan kepatuhan menelan obat $(p$-value $=0,002$ dan $\mathrm{OR}=$ $9,167)$ dengan kegagalan konversi pada pasien tuberculosis.

Simpulan: Terdapat hubungan para perokok aktif, kepatuhan menelan obat dan kegagalan konversi (BTA positif) pada pasien tuberculosis. Perlu lebih ditingkatkannya dukungan PMO serta peran petugas kesehatan dalam meningkatkan kepatuhan berobat pasien dan motivasi dalam menghentikan kebiasaan merokok.

Kata Kunci: Perokok aktif; Kepatuhan menelan Obat; Kegagalan konversi; (BTA positif); Tuberculosis 
Kepatuhan menelan obat, merokok dan resiko kegagalan konversi (BTA positif) pada pasien tuberculosis

\section{PENDAHULUAN}

Angka kesakitan dan kematian penyakit merupakan indikator dalam menilai derajat kesehatan suatu masyarakat. Pengendalian penyakit merupakan upaya penurunan insidensi, prevalensi, morbiditas atau mortalitas dari suatu penyakit hingga level yang dapat diterima secara lokal. Pengendalian penyakit meliputi pengendalian penyakit menular dan tidak menular (Kementerian Kesehatan Republik Indonesia, 2017).

Salah satu penyakit menular yang sering diderita masyarakat adalah Tuberculosis paru (TB paru). Tuberkulosis disebabkan oleh infeksi bakteri Mycobacterium tuberculosis. Sumber penularan adalah pasien tuberkulosis Basil Tahan Asam positif (BTA positif) melalui percik renik dahak yang dikeluarkannya (Tanto, Liwang, Hanifati, \& Pradipta, 2014).

Tuberkulosis merupakan penyakit yang menjadi perhatian global. Sesuai dengan tujuan Pembangunan Berkelanjutan 2030, World Health Organitation (WHO) menargetkan untuk menurunkan kematian akibat tuberkulosis sebesar $90 \%$ dan menurunkan insidens sebesar $80 \%$ pada tahun 2030 dibandingkan dengan tahun 2014. Pada tahun 2015 diperkirakan terdapat 10,4 juta kasus baru tuberkulosis atau 142 kasus/100.000 populasi, dengan 480.000 kasus gagal konversi. Indonesia merupakan negara dengan jumlah kasus baru terbanyak kedua di dunia setelah India. Sebesar $60 \%$ kasus baru terjadi di 6 negara yaitu India, Indonesia, China, Nigeria, Pakistan dan Afrika Selatan. Kematian akibat tuberkulosis diperkirakan sebanyak 1,4 juta kematian ditambah 0,4 juta kematian akibat tuberkulosis pada orang dengan HIV. Angka keberhasilan pengobatan di Indonesia juga masih rendah, yaitu $85 \%$ (World Health Organization, 2014; Astuti, 2013).

Data Provinsi Lampung, jumlah pasien baru yang ditemukan dan tercatat di antara 100.000 penduduk di Lampung masih cukup tinggi, yaitu mencapai 110 per 100.000 penduduk, dengan angka keberhasilan pengobatan sebesar 86,9\% (Target $\geq 90 \%$ ) (Kementerian Kesehatan Republik Indonesia, 2017). Data di Kabupaten Lampung Tengah pada tahun 2017 BTA (+) kasus baru yang ditemukan sebanyak 954 kasus dari 20.184 orang suspek (4,73\%), jumlah ini mengalami peningkatan jika dibandingkan dengan tahun 2016 BTA (+) yaitu sebanyak 748 kasus dari 20.076 orang suspek
$(3,73 \%)$ (Dinas Kesehatan Lampung Tengah, 2018).

Salah satu upaya untuk mengendalikan tuberkulosis yaitu dengan pengobatan. Indikator yang digunakan untuk mengevaluasi pengobatan tuberkulosis melalui angka keberhasilan pengobatan (Success Rate). Angka keberhasilan pengobatan merupakan jumlah semua kasus tuberkulosis yang sembuh (cure) dan pengobatan lengkap di antara semua kasus tuberkulosis yang diobati dan dilaporkan (Smeltzer, \& Bare, 2012). Sedangkan konversi dahak dan biakan merupakan indikator respons pengobatan. Konversi biakan dilakukannya pemeriksaan biakan 2 kali berurutan dengan jarak pemeriksaan 30 hari menunjukkan hasil negatif (Kementerian Kesehatan Republik Indonesia, 2014).

Angka konversi dan angka kesembuhan saling berkaitan. Perubahan hasil BTA positif pada awal pengobatan dan negatif pada akhir pengobatan fase intensif disebut konversi. Konversi yang tinggi akan diikuti dengan kesembuhan yang tinggi sehingga akan berdampak pada keberhasilan pengobatan TB (Kurniati, 2010; Riza, 2015).

Keberhasilan pengobatan TB paru juga berkaitan dengan kepatuhan pasien dalam menelan obat. Kepatuhan atau ketaatan (compliance/adherence) dimana pasien dapat melaksanakan cara pengobatan dan perilaku yang disarankan oleh dokternya atau orang lain. Penderita yang patuh berobat dapat menyelesaikan pengobatan secara teratur dan lengkap tanpa terputus selama minimal 6 bulan sampai dengan 9 bulan. Untuk tercapainya hal tersebut, sangat penting dipastikan bahwa pasien menelan seluruh obat yang diberikan sesuai anjuran dengan cara pengawasan langsung oleh seorang PMO (Pengawas Menelan Obat) agar mencegah terjadinya resistensi obat (Badan Pengawas Obat dan Makanan Republik Indonesia, 2017; Sutoyo, 2010).

Selain itu, untuk meningkatkan keberhasilan pengobatan dan mencegah resistensi obat juga dapat dilakukan dengan menghentikan kebiasaan merokok. Zat kimia berbahaya yang terkandung dalam rokok maupun asap rokok masuk kedalam tubuh dan merusak sebagian mekanisme pertahanan paru sehingga mengganggu kebersihan mukosilier dan mengakibatkan terjadinya penurunan fungsi makrofag alveolar paru untuk fagositosis. Sehingga kebiasaan

\footnotetext{
Mariawati ${ }^{i *}$ Puskesmas Poncowati Lampung Tengah. *Email: mariawati0678@gmail.com

Khoidar Amirus ${ }^{2}$ Fakultas Kesehatan Masyarakat, Universitas Malahayati

Marliyana ${ }^{3}$ Akademi Keperawatan Baitul Hikmah Bandar Lampung
} 
Kepatuhan menelan obat, merokok dan resiko kegagalan konversi (BTA positif) pada pasien tuberculosis

merokok yang dilakukan terus-menerus menyebabkan fungsi sistem imun melemah dan memperparah penyakit tuberkulosis paru akibatnya masih terdapat kuman TB dalam tubuh yang mengakibatkan terjadinya gagal konversi (Bangun, 2008; Riza, 2015).

Hasil penelitian tentang faktor yang berhubungan dengan non-konversi BTA positif pada pengobatan tuberkulosis diperoleh hasil bahwa sebanyak 27,3\% pasien yang tidak patuh menelan obat mengalami kegagalan konversi (Marizan, Mahendradhata, \& Wibowo, 2016). Selain itu, penelitian lainnya tentang hubungan perilaku merokok dengan kejadian gagal konversi pasien tuberkulosis diperoleh hasil bahwa sebanyak $60,4 \%$ pasien TB yang merokok mengalami kegagalan konversi saat pengobatan (Riza, 2015).

Pada tahun 2016 jumlah pasien tuberkulosis paru sebanyak 32 orang dan pada tahun 2017 meningkat menjadi 37 orang, dan kembali meningkat menjadi 42 orang pada 2018. Angka kegagalan konversi cukup tinggi yaitu sebanyak 16 orang dari 42 orang penderita TB paru $(38,1 \%)$, dan keberhasilan pengobatan juga masih rendah, yaitu $76,2 \%$ (target $>90 \%$ ) (Dinas Kesehatan Lampung Tengah, 2018). Selain itu, data pada trimester awal tahun 2019, angka kegagalan konversi sebanyak 16 orang dari 42 orang penderita TB paru $(38,1 \%)$. Hasil wawancara pada 5 orang penderita TB (dari 16 orang yang mengalami kegagalan konversi dipilih secara random) diketahui 4 orang $(80 \%)$ penderita Tuberkulosis Paru tersebut adalah memiliki perilaku merokok aktif dan juga dari 5 orang tersebut 3 orang $(60 \%)$ pernah putus obat.

\section{METODE PENELITIAN}

Jenis penelitian kuantitatif, rancangan dengan analitik observasional, dan pendekatan secara cross sectional. Penelitian ini sudah lulus kelaikan etik dari Komisi Etik Penelitian Kesehatan Universitas Malahayati pada bulan Mei 2019. Surat layak etik nomor 1004/EC/KEP-UNMAL/IV/2019 tgl 14 april 2019. Tempat penelitian di Puskesmas Poncowati Lampung Tengah dan dilakukan pada bulan Juli 2019. Jumlah sampel sebanyak 42 responden dan teknik pengambilan sampel menggunakan total sampling.

Untuk melihat kepatuhan minum obat dengan cara : sedangkan dengan kepatuhan minum obat menggunakan lembar kuesioner Jawaban responden tentang frekuensi minum obat secara teratur setiap hari sesuai paket obat selama dua bulan pengobatan fase intensif. (Amaliah, 2012).

Dengan skor 1 = Tidak patuh (Bila skor < median) 2 = Patuh (Bila skor = median). Alat pengumpulan data berupa kuesioner yang berisi pertanyaan tentang kepatuhan menelan obat dengan jumlah pertanyaan 15 soal yang telah digunakan oleh peneliti sebelumnya dan telah diuji validitas.

Untuk melihat merokok kategori aktif dan tidak aktif dengan melihat Perilaku merokok Suatu aktivitas membakar dan menghisap rokok serta menimbulkan asap rokok yang dapat terhisap oleh orang yang ada di sekitarnya setelah pasien dinyatakan TB paru BTA positif dan menjalani pengobatan awal fase intensif selama dua bulan (Riza, 2015). Usia mulai merokok Usia pertama kali responden mulai mengkonsumsi dan menghisap rokok yang dihitung dalam tahun (Bustan, 2007).

Lama riwayat merokok Rentan waktu dari usia responden mulai merokok hingga pasien dinyatakan TB paru dan telah menjalani pengobatan awal fase intensif selama dua bulan (Haris, 2013). Jumlah rokok yang dihisap per hari Jumlah rata-rata batang rokok yang dihisap setiap harinya oleh responden setelah responden dinyatakan TB paru dan menjalani pengobatan awal fase intensif selama dua bulan (Haris, 2013). Jenis rokok yang biasa dihisap setiap harinya oleh responden setelah responden dinyatakan TB paru dan menjalani pengobatan awal fase intensif selama dua bulan yang didasarkan pada penggunaan filter (Riza, 2015).

Dengan jumlah skor tertinggi 10 dan skor terendah 5 , bila mendapatkan nilai 6 dikatakan perokok aktif dan untuk melihat kegagalan konversi yaitu Gagal konversi TB adalah Penderita tuberkulosis paru dengan hasil pemeriksaan BTA positif pada awal pengobatan dan tetap positif pada saat evaluasi pengobatan intensif dua bulan (Amaliah, 2012).

Dengan cara hasil lab seluruh responden.Data diambil dari responden dengan melakukan wawancara dan data rekam medik. Analisis menggunakan pengujian statistik rumus chi-square dengan taraf yang digunakan adalah $5 \%$ atau $p$ value 0,05

\footnotetext{
Mariawati ${ }^{i *}$ Puskesmas Poncowati Lampung Tengah. *Email: mariawati0678@gmail.com

Khoidar Amirus ${ }^{2}$ Fakultas Kesehatan Masyarakat, Universitas Malahayati

Marliyana ${ }^{3}$ Akademi Keperawatan Baitul Hikmah Bandar Lampung
} 
Kepatuhan menelan obat, merokok dan resiko kegagalan konversi (BTA positif) pada pasien tuberculosis

HASIL

Tabel 1. Distribusi Frekuensi Karakteristik Responden N = 42

\begin{tabular}{|c|c|c|}
\hline Variabel & $\mathrm{N}(\%)$ & MESD \\
\hline $\begin{array}{l}\text { Umur: } \\
\text { (tahun) (rentang 20-60) }\end{array}$ & $42(100 \%)$ & $37.05 \pm 34.00(20-60)$ \\
\hline Jenis kelamin & & \\
\hline Laki & $38(90.5 \%)$ & \\
\hline Perempuan & $4(9.5 \%)$ & \\
\hline $\begin{array}{l}\text { Pendidikan: } \\
\text { SD } \\
\text { SMP } \\
\text { SMA } \\
\text { Perguruan Tinggi }\end{array}$ & $\begin{array}{c}10(23.8 \%) \\
4(9.5 \%) \\
26(61.9 \%) \\
2(4.8 \%)\end{array}$ & \\
\hline $\begin{array}{l}\text { Pekerjaan: } \\
\text { Buruh } \\
\text { IRT } \\
\text { Karyawan } \\
\text { Petani } \\
\text { Wiraswasta }\end{array}$ & $\begin{array}{c}5(11.9 \%) \\
12(28.6 \%) \\
2(4.8 \%) \\
18(42.9 \%) \\
5(11.9 \%)\end{array}$ & \\
\hline $\begin{array}{l}\text { Status ekonomi: } \\
\text { Rendah } \\
\text { Sedang } \\
\text { Tinggi }\end{array}$ & $\begin{array}{l}21(50 \%) \\
16(38.1 \%) \\
5(11.9 \%)\end{array}$ & \\
\hline $\begin{array}{l}\text { Merokok aktif : } \\
\text { Tidak beresiko } \\
\text { Beresiko }\end{array}$ & $\begin{array}{l}22(52.4 \%) \\
20(47.6 \%)\end{array}$ & \\
\hline $\begin{array}{l}\text { Kepatuhan menelan obat } \\
\text { Patuh } \\
\text { Tidak patuh }\end{array}$ & $\begin{array}{l}28(66.7 \%) \\
14(33.3 \%)\end{array}$ & \\
\hline $\begin{array}{l}\text { Lamanya menderita TBC } \\
\text { (bulan) (rentang 1-12) }\end{array}$ & $42(100 \%)$ & $7.21 \pm 7.00(1-12)$ \\
\hline
\end{tabular}

Berdasarkan tabel 1 dapat diketahui bahwa berdasarkan umur, sebagian besar responden memiliki umur 38 tahun dengan rata-rata (mean) 37.05 tahun \pm 34.00 . Berdasarkan pendidikan, diketahui bahwa sebagian besar responden berpendidikan SMA, yaitu sebanyak 26 orang (61.9\%). Selain itu berdasarkan pekerjaan, diketahui bahwa sebagian besar responden bekerja sebagai petani, yaitu sebanyak 18 orang (42.9\%). Berdasarkan status ekonomi , diketahui Sebagian besar responden mempunyai status ekonomi rendah yaitu sebanyak 21 responden $(50.00 \%)$.Sebagian besar responden merokok $<10$ batang perhari (tidak berisiko) yaitu sebanyak 22 orang $(52.4 \%)$. Diketahui bahwa sebagian besar responden patuh dalam menelan obat, yaitu sebanyak 28 orang (66.7\%). Berdasarkan lamanya menderita TBC diketahui Sebagian besar responden menderita TBC selama 8 bulan dengan rata rata (mean) 7.21 bulan \pm 7.00 . 
Kepatuhan menelan obat, merokok dan resiko kegagalan konversi (BTA positif) pada pasien tuberculosis

Tabel 2. Hubungan Variabel Dengan Konversi $\mathrm{N}=42$

\begin{tabular}{|c|c|c|c|c|c|c|}
\hline \multirow[t]{3}{*}{ Variabel } & \multicolumn{4}{|c|}{ Konversi } & \multirow[t]{3}{*}{$p$-value } & \multirow{3}{*}{$\begin{array}{c}\text { OR } \\
\text { (Cl 95\%) }\end{array}$} \\
\hline & \multicolumn{2}{|c|}{ Berhasil } & \multicolumn{2}{|c|}{ Gagal } & & \\
\hline & $\mathrm{n}$ & $\%$ & $\mathrm{n}$ & $\%$ & & \\
\hline \multicolumn{7}{|l|}{ Merokok Aktif } \\
\hline Tidak berisiko & 19 & 45.2 & 3 & 7.1 & 0.002 & 11.762 \\
\hline Berisiko & 7 & 17.0 & 13 & 31.0 & & $(2,559-54,071)$ \\
\hline \multicolumn{7}{|l|}{ Kepatuhan } \\
\hline Patuh & 22 & 52.4 & 6 & 14.3 & 0,005 & 9,167 \\
\hline Tidak patuh & 4 & 9.5 & 10 & 23.8 & & $(2,109-39,847)$ \\
\hline
\end{tabular}

Berdasarkan tabel 2. diatas dapat dilihat bahwa dari 22 responden yang merokok $<10$ batang/hari (tidak berisiko), sebagian besar mengalami konversi yaitu sebanyak 19 orang (45.2\%), sedangkan 3 orang $(7.1 \%)$ lainnya mengalami kegagalan konversi. Selain itu dari 20 responden yang merokok $\geq 10$ batang/hari (berisiko), sebagian besar mengalami kegagalan konversi yaitu sebanyak 13 orang $(31.0 \%)$, sedangkan 7 orang $(17.0 \%)$ lainnya tidak mengalami kegagalan konversi.

Hasil analisis menggunakan chi-square, didapatkan $p$-value $=0,002$, sehingga $p$-value $<a$ $(0,002<0,05)$ maka Ho ditolak. Jadi dapat disimpulkan terdapat hubungan antara perokok aktif dengan kejadian kegagalan konversi pada pasien tuberculosis. Selain itu, berdasarkan hasil perhitungan statistik diperoleh juga nilai Odd Ratio (OR) yaitu sebesar 11,762 . Artinya pasien yang merokok aktif $\geq 10$ batang perhari memiliki risiko 11,762 kali mengalami kegagalan konversi dibandingkan pasien yang tidak merokok aktif.

Sedangkan dalam kepatuhan menelan obat dapat dilihat bahwa dari 28 responden yang patuh dalam menelan obat, sebagian besar mengalami konversi yaitu sebanyak 22 orang (52.4\%), sedangkan 6 orang (14.3\%) lainnya mengalami kegagalan konversi. Selain itu dari 14 responden yang tidak patuh dalam menelan obat, sebagian besar mengalami kegagalan konversi yaitu sebanyak 10 orang $(23.8 \%)$, sedangkan 4 orang $(9.5 \%)$ lainnya tidak mengalami kegagalan konversi.

Hasil analisis menggunakan chi-square, didapatkan $p$-value $=0,005$, sehingga $p$-value $<a$ $(0,005<0,05)$ maka Ho ditolak. Jadi dapat disimpulkan terdapat hubungan antara kepatuhan menelan obat dengan kejadian kegagalan konversi pada pasien tuberculosis. Selain itu, berdasarkan hasil perhitungan statistik diperoleh juga nilai Odd Ratio (OR) yaitu sebesar 9,167. Artinya pasien yang tidak patuh dalam menelan obat memiliki risiko 9,167 kali mengalami kegagalan konversi dibandingkan pasien yang patuh menelan obat.

\section{PEMBAHASAN \\ Merokok Aktif}

Berdasarkan hasil penelitian diperoleh bahwa sebagian besar responden merokok $<10$ batang perhari (tidak berisiko) yaitu sebanyak 22 orang $(52,4 \%)$.

Hasil penelitian ini sesuai dengan teori yang menyebutkan bahwa pasien TB paru yang merokok $\geq 10$ batang perhari memiliki risiko dua kali mengalami gagal konversi BTA positif (Haris, Thaha, \& Abdullah, 2013; Riza, 2015). Rokok merupakan silinder dari kertas berukuran panjang sekitar 120 milimeter dengan diameter sekitar 10 milimeter yang berisi daun-daun tembakau yang telah dicacah. Rokok dibakar pada salah satu ujungnya dan dibiarkan membara agar asapnya dapat dihirup lewat mulut pada ujung lain (Mukminah, 2017). Sebatang rokok di dalamnya terkandung lebih dari 4000 Jenis senyawa kimia, 400 zat berbahaya (Mangoenprasodjo, \& Hidayati, 2013).

Hasil penelitian ini juga sejalan dengan penelitian sebelumnya tentang hubungan perilaku merokok dengan kejadian gagal konversi pasien tuberkulosis diperoleh hasil bahwa sebanyak $41.9 \%$ pasien yang merokok mengalami kegagalan konversi (Riza, 2015).

Menurut asumsi peneliti, sebagian besar responden dalam kategori tidak berisiko merokok

Mariawati"* Puskesmas Poncowati Lampung Tengah. *Email: mariawati0678@gmail.com

Khoidar Amirus ${ }^{2}$ Fakultas Kesehatan Masyarakat, Universitas Malahayati

Marliyana ${ }^{3}$ Akademi Keperawatan Baitul Hikmah Bandar Lampung 
Kepatuhan menelan obat, merokok dan resiko kegagalan konversi (BTA positif) pada pasien tuberculosis

aktif $(<10$ batang perhari) disebabkan karena sebagian besar responden telah memiliki kesadaran yang baik dalam menjaga kesehatannya serta memiliki keinginan yang tinggi untuk sembuh dari penyakitnya, sehingga apa yang disarankan oleh tenaga kesehatan termasuk untuk menghentikan kebiasaan merokok dapat dilaksanakan dengan baik. Walaupun merokok merupakan suatu perilaku yang telah menjadi kebiasaan yang sulit dihilangkan, namun ada kalanya perilaku tersebut dapat diubah dengan motivasi dan pengetahuan yang baik. Hal ini mungkin terkait dengan tingkat pendidikan responden yang sebagian besar berpendidikan SMA, sehingga akan lebih mudah bagi tenaga kesehatan dalam mentransfer informasi serta memotivasi responden untuk tidak merokok.

\section{Kepatuhan Menelan Obat}

Berdasarkan hasil penelitian diperoleh bahwa sebagian besar responden patuh dalam menelan obat, yaitu sebanyak 28 orang $(66,7 \%)$.

Hasil penelitian ini sesuai dengan teori bahwa salah satu upaya untuk mengendalikan TB yaitu dengan pengobatan. Indikator yang digunakan sebagai evaluasi pengobatan yaitu angka keberhasilan pengobatan (success rate). Angka keberhasilan pengobatan ini dibentuk dari angka kesembuhan (cure rate) dan angka pengobatan lengkap (Smeltzer, \& Bare, 2012). Kepatuhan (adherence) secara umum sebagai tingkatan perilaku seseorang yang mendapatkan pengobatan, mengikuti diet, dan melaksanakan gaya hidup sesuai dengan rekomendasi pemberi pelayanan kesehatan (Kementerian Kesehatan Republik Indonesia, 2014).

Sejalan dengan penelitian lainnya tentang faktor yang berhubungan dengan non-konversi BTA positif pada pengobatan tuberkulosis paru diperoleh hasil bahwa sebanyak $27,3 \%$ pasien yang tidak patuh menelan obat mengalami kegagalan konversi (Marizan, Mahendradhata, \& Wibowo, 2016). Ketidakpatuhan menelan obat ini dapat disebabkan beberapa faktor penentu seperti kompleksitas prosedur pengobatan, derajat perubahan gaya hidup yang dibutuhkan, lamanya waktu di mana pasien harus mematuhi nasihat tersebut, serta keparahan penyakit yang dipersepsikan sendiri oleh pasien dan bukan profesional kesehatan (Niven, 2010).
Menurut asumsi peneliti, sebagian besar responden patuh dalam menelan obat disebabkan karena berbagai macam faktor salah satunya adalah dukungan pengawas menelan obat (PMO) yang baik. Dukungan pengawas menelan obat sangat berperan penting dalam keberhasilan pengobatan TB. Dukungan yang baik akan mengakibatkan kepatuhan pasien TB dalam menelan obat, sehingga dapat mencegah risiko terjadinya resistensi kuman penyebab TB. Kemudian selain itu, faktor pendidikan juga berpengaruh terhadap kepatuhan responden dalam menelan obat. Hal ini dikarenakan pendidikan akan berbanding lurus dengan pengetahuan yang dimiliki. Berdasarkan hasil penelitian diperoleh bahwa sebagian besar responden memiliki pendidikan terakhir SMA. Hal ini menunjukkan bahwa tingkat pendidikan responden sudah cukup baik sehingga responden memiliki kemampuan untuk menerima informasi dengan baik dari tenaga kesehatan yang memberikan informasi tentang penyakit tuberculosis terutama tentang pengobatan TB Paru.

\section{Hubungan Merokok Aktif Dengan Kejadian Kegagalan Konversi}

Berdasarkan hasil penelitian diperoleh bahwa terdapat hubungan antara perokok aktif dengan kejadian kegagalan konversi pada pasien tuberculosis ( $p$-value $=0,002$ dan OR= 11,762).

Sesuai dengan teori bahwa dampak rokok untuk jangka panjang yaitu dapat mengalami infeksi saluran pernafasan, dimana merokok $\geq 10$ batang/hari mempermudah timbulnya dan mempersulit penyembuhan radang tenggorokan, sinusitis, bronchitis, TB paru, dan radang paruparu, dibanding mereka yang tidak merokok (Nurarif, \& Kusuma, 2015).

Hasil penelitian ini juga sejalan dengan penelitian terdahulu tentang hubungan perilaku merokok dengan kejadian gagal konversi pasien tuberkulosis diperoleh hasil bahwa terdapat hubungan yang bermakna antara perilaku merokok, lama riwayat merokok,dan jumlah rokok yang dihisap per hari dengan kejadian gagal konversi nilai $p$-value $<0,05$ (Riza, 2015).

Menurut asumsi peneliti, adanya hubungan antara perokok aktif dengan kejadian kegagalan konversi pada pasien tuberculosis disebabkan karena kandungan zat kimia berbahaya dalam

\footnotetext{
Mariawati ${ }^{i *}$ Puskesmas Poncowati Lampung Tengah. *Email: mariawati0678@gmail.com

Khoidar Amirus ${ }^{2}$ Fakultas Kesehatan Masyarakat, Universitas Malahayati

Marliyana ${ }^{3}$ Akademi Keperawatan Baitul Hikmah Bandar Lampung
} 
Kepatuhan menelan obat, merokok dan resiko kegagalan konversi (BTA positif) pada pasien tuberculosis

rokok dan asap rokok yang dapat menyebabkan kuman tuberculosis mudah menginfeksi dimana kebiasaan merokok yang dilakukan terus-menerus oleh pasien tuberkulosis paru akan dapat memperlemah mekanisme pertahanan paru sehingga akan memperparah penyakit tersebut. Hal ini sesuai dengan hasil penelitian yang diperoleh bahwa responden yang tidak berisiko dalam merokok aktif cenderung mengalami konversi $(86,4 \%)$. Selain itu responden yang berisiko dalam merokok aktif, sebagian besar mengalami kegagalan konversi (65\%). Komponen kimia berbahaya yang yang terkandung dalam asap rokok yang dihisap akan masuk kedalam tubuh dan merusak mekanisme pertahanan paru sehingga mengganggu mukosilier dalam paru dan mengakibatkan terjadinya penurunan fungsi pertahanan yaitu makrofag alveolar paru untuk melakukan fagositosis. Sehingga kebiasaan merokok yang dilakukan terus menerus menyebabkan fungsi sistem imun melemah dan memperparah penyakit tuberkulosis paru. Penurunan fungsi makrofag ini juga dapat menyebabkan kuman mycobacterium tuberculosis dapat bebas melakukan replikasi dan menyebabkan resistensi kuman terhadap obat tertentu, akibatnya masih terdapat kuman TB dalam tubuh yang mengakibatkan terjadinya gagal konversi.

Hasil penelitian juga diperoleh bahwa terdapat sebagian dari responden yang tidak berisiko dalam merokok aktif namun mengalami kegagalan konversi $(13,6 \%)$. Hal ini dapat disebabkan karena kegagalan konversi dipengaruhi oleh faktor lain selain merokok aktif, misalnya oleh kepatuhan menelan obat atau juga oleh faktor lain yang tidak diteliti misalnya kegagalan konversi dapat dipengaruhi oleh pasien pindah fasilitas pelayanan kesehatan, TB nya termasuk yang resisten terhadap OAT, faktor pengawas minum obat (PMO), suplai OAT terganggu sehingga pasien menunda atau tidak meneruskan minum obat dan kualitas OAT menurun karena penyimpanan tidak sesuai standar. Selain itu, terdapat sebagian dari responden yang berisiko dalam merokok aktif namun mengalami konversi (35\%). Hal ini dapat disebabkan karena keberhasilan konversi dipengaruhi oleh faktor lain selain karena faktor merokok aktif, misalnya karena walaupun pasien perokok aktif namun belum berlangsung lama sedangkan ia juga patuh dalam menelan obat.

\section{Hubungan Kepatuhan Menelan Obat Dengan Kejadian Kegagalan Konversi}

Berdasarkan hasil penelitian diperoleh bahwa terdapat hubungan antara kepatuhan menelan obat dengan kejadian kegagalan konversi pada pasien tuberculosis ( $p$-value $=0,002$ dan OR= 9,167).

Sesuai dengan teori yang dikemukakan bahwa kepatuhan menelan obat merupakan salah satu faktor yang menyebabkan resistensi obat. Ketika obat tuberkulosis harus diminum oleh penderita secara rutin selama enam bulan berturut-turut tanpa henti, kedisiplinan pasien dalam menjalankan pengobatan juga perlu diawasi oleh anggota keluarga terdekat yang tinggal serumah, yang setiap saat dapat mengingatkan penderita untuk minum obat (Sarwani, \& Nurlaela, 2012).

Hasil penelitian ini juga sejalan dengan penelitian sebelumnya tentang faktor yang berhubungan dengan non-konversi BTA positif pada pengobatan tuberkulosis diperoleh hasil bahwa terdapat hubungan antara kepatuhan menelan obat dengan kegagalan konversi dengan $\mathrm{OR}=1,4$ (Marizan, Mahendradhata, \& Wibowo, 2016).

Menurut asumsi peneliti, adanya hubungan antara kepatuhan menelan obat dengan kejadian kegagalan konversi pada pasien tuberculosis disebabkan karena keteraturan minum obat merupakan faktor risiko terjadinya kegagalan konversi dimana obat merupakan metode utama untuk mengeliminasi kuman penyebab tuberculosis. Hal ini sesuai dengan hasil penelitian yang diperoleh bahwa responden yang patuh dalam menelan obat cenderung mengalami konversi $(78,6 \%)$. Selain itu responden yang tidak patuh dalam menelan obat cenderung mengalami kegagalan konversi $(71,4 \%)$. Gagal atau tidaknya konversi tergantung dari pengobatan. Obat Anti Tuberkulosis (OAT) harus diminum selama fase intensif. Obat Anti Tuberkulosis (OAT) harus ditelan secara teratur sesuai dengan jadwal pada fase pengobatan untuk menghindari terjadinya kegagalan pengobatan dan kekambuhan. Pengobatan TB pada fase intensif perlu dilakukan sesuai prosedur dan jadwal karena ketidaktepatan pelaksanaan pengobatan ini yaitu apabila penderita TB tidak teratur minum obat akan dapat mempengaruhi penyembuhan bahkan mengakibatkan resistensi kuman TB terhadap OAT. Apabila pasien menjadi kebal terhadap obat,

Mariawati"* Puskesmas Poncowati Lampung Tengah. *Email: mariawati0678@gmail.com

Khoidar Amirus ${ }^{2}$ Fakultas Kesehatan Masyarakat, Universitas Malahayati

Marliyana ${ }^{3}$ Akademi Keperawatan Baitul Hikmah Bandar Lampung 
Kepatuhan menelan obat, merokok dan resiko kegagalan konversi (BTA positif) pada pasien tuberculosis

maka akan membutuhkan waktu yang lebih lama untuk sembuh dan juga akan berdampak pada kegagalan konversi.

Hasil penelitian juga diperoleh bahwa terdapat sebagian dari responden yang patuh dalam menelan obat namun mengalami kegagalan konversi $(21,4 \%)$. Hal ini dapat disebabkan karena kegagalan konversi dipengaruhi oleh faktor lain selain kepatuhan menelan obat, misalnya responden memiliki risiko perokok aktif (> 10 batang per hari) sehingga walaupun patuh dalam menelan obat namun kuman TB akan lebih resisten terhadap obat dikarenakan kebiasaan merokok yang buruk tersebut. Selain itu, terdapat sebagian dari responden yang tidak patuh dalam menelan obat namun mengalami konversi $(28,6 \%)$. Hal ini dapat disebabkan karena keberhasilan konversi tersebut dipengaruhi oleh faktor lain selain kepatuhan menelan obat, misalnya ketidakpatuhannya hanya telat satu kali minum obat dan juga kondisi paru-parunya belum terlalu buruk karena pasien juga tidak merokok aktif.

\section{SIMPULAN}

Sebagian besar responden merokok $<10$ batang perhari (tidak berisiko) yaitu sebanyak 22 orang $(52,4 \%)$.Sebagian besar responden patuh dalam menelan obat, yaitu sebanyak 28 orang $(66,7 \%)$. Terdapat hubungan antara perokok aktif dengan kejadian kegagalan konversi pada pasien tuberculosis ( $p$-value $=0,002$ dan OR= 11,762). Terdapat hubungan antara kepatuhan menelan obat dengan kejadian kegagalan konversi pada pasien tuberculosis ( $p$-value $=0,002$ dan $\mathrm{OR}=$ 9,167).

\section{SARAN}

Perlu lebih ditingkatkannya dukungan PMO dengan lebih meningkatkan pengetahuan dan motivasi PMO serta melakukan penyuluhan kesehatan secara rutin kepada masyarakat yang berisiko menderita TB paru. Diharapkan bagi peneliti selanjutnya untuk dapat meningkatkan hasil penelitiannya dengan ruang lingkup atau jumlah sampel yang lebih besar, serta meneliti faktor yang belum diteliti yang berhubungan dengan kegagalan konversi misalnya pengetahuan, sikap, atau motivasi pasien.

\section{DAFTAR PUSTAKA}

Amaliah, R. (2012). Faktor-faktor yang berhubungan dengan kegagalan konversi penderita TB Paru BTA Positif pengobatan fase intensif di Kabupaten Bekasi tahun 2010. Depok. Universitas Indonesia.

Astuti, S. (2013). Hubungan tingkat pengetahuan dan sikap masyarakat terhadap upaya pencegahan penyakit Tuberkulosis di RW 04 Kelurahan Lagoa Jakarta Utara Tahun 2013.

Badan Pengawas Obat dan Makanan Republik Indonesia. (2017). Informatorium Obat Nasional Indonesia (IONI), Badan Pengawas Obat dan Makanan Republik Indonesia.

Bangun, A. P. (2008). Sikap Bijak Bagi Perokok. Bentara cipta prima: Jakarta.

Bustan, N. (2007). Epidemologi Penyakit Tidak Menular Jakarta.

Dinas Kesehatan Lampung Tengah. (2018). Profil Kesehatan Puskesmas Poncowati. Lampung Tengah: Dinas Kesehatan Lampung Tengah.

Haris, D. R. S., Thaha, I. L., \& Abdullah, A. Z. (2013). Asosiasi Perilaku Merokok Terhadap Kejadian Konversi pada Pasien TB Paru di Rumah Sakit dan Balai Besar Kesehatan Paru Masyarakat Kota Makassar. Makassar: Universitas Hasanudin.

Kementerian Kesehatan Republik Indonesia. (2014). Pedoman nasional pengendalian tuberkulosis. Direktorat Jendral Pengendalian Penyakit Dan Penyehatan Lingkungan, Jakarta, Indonesia, ISBN, 978-979.

Kementerian Kesehatan Republik Indonesia. (2017). Data dan informasi profil kesehatan Indonesia 2016. Jakarta: Pusat Data dan Informasi Kementerian Kesehatan RI.

Kurniati, I. (2010). Angka Konversi Penderita Tuberkulosis Paru yang Diobati dengan Obat Antituberkulosis (OAT) Paket Kategori Satu di BP4 Garut. Majalah Kedokteran Bandung, 42(1), 32-36.

Mariawati'* Puskesmas Poncowati Lampung Tengah. *Email: mariawati0678@gmail.com

Khoidar Amirus ${ }^{2}$ Fakultas Kesehatan Masyarakat, Universitas Malahayati

Marliyana ${ }^{3}$ Akademi Keperawatan Baitul Hikmah Bandar Lampung 
Kepatuhan menelan obat, merokok dan resiko kegagalan konversi (BTA positif) pada pasien tuberculosis

Mangoenprasodjo, A. S., \& Hidayati, S. N. (2013). Hidup Sehat Tanpa Rokok. Yogyakarta: Pradipta Publishing.

Marizan, M., Mahendradhata, Y., \& Wibowo, T. A. (2016). Faktor yang berhubungan dengan nonkonversi BTA positif pada pengobatan tuberkulosis paru di kota Semarang. Berita Kedokteran Masyarakat, 32(3), 77-82.

Mukminah, M. (2017). Hubungan monitoring parental dan kebiasaan peer group dengan perilaku merokok remaja SLTP di Kota Mataram. Jurnal Biosains, 3(3), 131-136.

Niven, N. (2010). Psikologi Kesehatan: Pengantar Untuk Perawat dan Profesional Kesehatan Lain, Edisi Kedua. Buku Kedokteran EGC, Jakarta

Nurarif, A. H., \& Kusuma, H. (2015). Nanda NicNoc: asuhan keperawatan berdasarkan diagnose medis. Jakarta: Edisi Revisi jilid, 1.

Nurarif, A. H., \& Kusuma, H. (2015). Nanda NicNoc: asuhan keperawatan berdasarkan diagnose medis. Jakarta: Edisi Revisi jilid, 1.
Riza, L. L. (2015). Hubungan Perilaku Merokok dengan Kejadian Gagal Konversi Pasien Tuberkulosis Paru di Balai Kesehatan Paru Masyarakat (BKPM) Wilayah Semarang (Doctoral dissertation, Universitas Negeri Semarang).

Sarwani, S.R, D., \& Nurlaela, S. (2012). Faktor risiko multidrug resistant tuberculosis (MDRTB). KEMAS: Jurnal Kesehatan Masyarakat, 8(1), 60-66.

Smeltzer,S. C., \& Bare, B. G. (2012). Keperawatan medikal bedah brunner \& suddarth. Jakarta: Penerbit Buku Kedokteran EGC.

Sutoyo, D K. (2010). Multi Drug Resistance (MDR) pada Tuberkulosis. Respir Indo.

Tanto, C., Liwang, F., Hanifati, S., \& Pradipta, E. A. (2014). Kapita selekta kedokteran. Jakarta: Media Aesculapius, 329-30.

World Health Organization. (2014). Drug-resistant TB: surveillance and response: supplement to global tuberculosis report 2014 (No. WHO/HQ/TB/2014.12). World Health Organization. 